\title{
THE KINETICS OF INDONESIAN GALENA CONCENTRATE LEACHING IN FLUOROSILICIC ACID AND HYDROGEN PEROXIDE AS ITS OXIDANTS
}

\author{
KINETIKA PELINDIAN KONSENTRAT GALENA INDONESIA \\ DALAM LARUTAN ASAM FLUOROSILIKAT DAN HIDROGEN \\ PEROKSIDA SEBAGAI OKSIDATOR
}

\author{
REZKY I. ANUGRAH ${ }^{1}$ and M. ZAKI MUBAROK ${ }^{2}$ \\ ${ }^{1}$ Research and Development Centre for Oil and Gas Technology "LEMIGAS" \\ Jalan Ciledug Raya Kaveling 109, Cipulir, Kebayoran Lama, \\ South Jakarta 12230, Indonesia \\ e-mail: rezkyia.2407@gmail.com \\ 2 Department of Metallurgical Engineering, Faculty of Mining and Petroleum Engineering, \\ Bandung Institute of Technology \\ Jalan Ganesha, 10, Bandung, 40132, West Java, Indonesia
}

\begin{abstract}
Lead smelting is known as a lead extraction technique which has negative impact to environment because it produces emissions of dust, $\mathrm{SO}_{2}$ gas and lead. The leaching is conducted to reduce the smelting's weaknesses by extracting the lead without damaging the environment. This technique, often called hydrometallurgical lead extraction, uses liquid media to extract the lead and separate it from the elemental sulphur $\left(\mathrm{S}^{0}\right)$ by filtration. Particle size, slurry density (solid percentage) and acid concentration affect the dissolution of Indonesian galena concentrate with fluorosilicic acid and hydrogen peroxide as oxidants. By means of these reagents, it is expected that the $\mathrm{Pb}$ extraction process from galena concentrate resulted from flotation of sulfide ore can be carried out at low temperatures and lead recovery can be accomplished from the leach solution by electrowining. Studying galena leaching kinetics is required to perform galena leaching with high $\mathrm{Pb}$ extraction percentages. Two kinetics models are commonly used to study leaching kinetics, namely shrinking core model (SCM) and shrinking particle model (SPM). These models are used to determine the mechanism which controls leach reaction and reaction rate constant or diffusion constant of the reacting species. Total plotting of sulfide fraction dissolves with time adjusted to the existing mathematical model, and fitting the curve from the dummy model to the experimental data, are two techniques that are utilized to obtain the best kinetics model which is important in controlling the leaching reaction rate. Applying the Arrhenius equation, the relation between the reaction rate constant or the diffusion constant and the temperature is determined to calculate the leaching activation energy. The result from kinetics analysis showed that the leaching of Indonesian galena concentrate in fluorosilicic acid with hydrogen peroxide as oxidants followed the shrinking core model with diffusion through porous solid product layer as the reaction controller with activation energy of $45.81 \mathrm{~kJ} / \mathrm{mol}$ or $10.91 \mathrm{kcal} / \mathrm{mol}$.
\end{abstract}

Keywords: galena concentrate, leaching, fluorosilicic acid, kinetics, activation energy.

\begin{abstract}
ABSTRAK
Peleburan timah dikenal sebagai teknik ekstraksi timah yang memiliki dampak negatif terhadap lingkungan karena menghasilkan emisi debu, gas $\mathrm{SO}_{2}$ dan timah. Pelindian hadir untuk mengurangi sejumlah kelemahan peleburan, dengan mengekstraksi timbal tanpa merusak lingkungan. Teknik ini, yang sering disebut ekstraksi timbal secara hidrometalurgi, menggunakan media cair untuk mengekstrak timbal dan memisahkannya dari unsur sulfur $\left(S^{0}\right)$ melalui penyaringan. Ukuran partikel, berat jenis bubur (persentase padatan) dan konsentrasi asam memengaruhi kelarutan konsentrat galena Indonesia dalam asam fluorosilikat dan hidrogen peroksida sebagai oksidator. Dengan menggunakan reagen-reagen
\end{abstract}


ini, diharapkan proses ekstraksi Pb dari konsentrat galena yang dihasilkan dari flotasi bijih sulfida dapat dilakukan pada suhu rendah dan perolehan timbal dapat dicapai dari larutan kaya dengan electrowinning. Mempelajari kinetika pelindian galena diperlukan untuk melakukan pelindian galena dengan persen ekstraksi Pb yang tinggi. Terdapat dua model kinetika yang biasa digunakan untuk mempelajari kinetika pelindian, yaitu model inti menyusut (SCM) dan model partikel menyusut (SPM). Kedua model ini digunakan untuk menentukan mekanisme yang mengendalikan reaksi pelindian dan konstanta laju reaksi atau konstanta difusi dari spesi-spesi yang bereaksi. Pengaluran fraksi sulfida total yang larut terhadap waktu yang disesuaikan dengan model matematika yang ada dan pencocokan kurva dari kurva dummy terhadap data percobaan adalah dua teknik yang digunakan untuk mendapatkan model kinetika terbaik yang memiliki peran terpenting dalam mengendalikan laju reaksi pelindian. Melalui penerapan persamaan Arrhenius, ditentukan hubungan konstanta laju reaksi atau konstanta difusi dengan suhu untuk menghitung energi aktivasi pelindian. Hasil analisis kinetika menunjukkan bahwa pelindian konsentrat galena Indonesia dalam asam fluorosilikat dan hidrogen peroksida sebagai oksidator mengikuti model inti menyusut dengan difusi melalui lapisan produk padat berpori sebagai pengendali reaksi yang memiliki energi aktivasi sebesar 45,81 kJ/mol atau 10,91 kkal/mol.

Kata kunci: konsentrat galena, pelindian, asam fluorosilikat, kinetika, energi aktivasi.

\section{INTRODUCTION}

Lead smelting is believed to have a number of impacts on the environment because it produces emissions of dust, $\mathrm{SO}_{2}$ gas and lead. To overcome such smelting's weaknesses, leaching is a promising process to extract lead without damaging the environment.

In hydrometallurgical lead extraction, sulphur is separated from the $\mathrm{Pb}$ as the elemental sulphur $\left(\mathrm{S}^{\circ}\right)$ and removed by filtration. The produced elemental sulfur is a porous solid and does not inhibit the dissolution of galena and becomes a sell-able by-product (Aydoğan et al., 2007). The dissolution of Indonesian galena concentrate in fluorosilicic acid and hydrogen peroxide as oxidants is affected by its particle size, slurry density (solid percentage) and acid concentration (Anugrah, Mubarok and Amalia, 2018). With fluorosilicic acid and hydrogen peroxide as oxidants it is expected that the $\mathrm{Pb}$ extraction process from galena concentrate resulting from flotation of sulfide ore can be carried out at low temperatures, and lead recovery can be carried out from the leach solution by electrowining. To perform galena leaching with high $\mathrm{Pb}$ extraction percentages, it is necessary to study its kinetics. Leaching kinetics were studied using a shrinking core model (SCM) and a shrinking particle model (SPM) as determinant mechanism which controls leach reaction and the reaction rate constant or diffusion constant of the reacting species. In this research, through the Arrhenius equation, the relation of the reaction rate constant or the diffusion constant is determined by temperature to calculate the leaching activation energy.

\section{METHOD}

Reaction kinetics provides information about the reaction rate until equilibrium is reached. Dissolution of $\mathrm{Pb}$ from galena with $\mathrm{H}_{2} \mathrm{SiF}_{6}$ in the presence of $\mathrm{H}_{2} \mathrm{O}_{2}$ may be performed through Eq.(1) while parts of sphalerite and pyrite in the concentrate will be also dissolved through Eq. (2) and (3) (Anugrah, Mubarok and Amalia, 2017).

$\mathrm{PbS}_{(\mathrm{S})}+\mathrm{H}_{2} \mathrm{SiF}_{6(\mathrm{aq})}+\mathrm{H}_{2} \mathrm{O}_{2(\mathrm{aq})} \rightarrow \mathrm{PbSiF}_{6(\mathrm{aq})}+\mathrm{S}^{\mathrm{O}}$

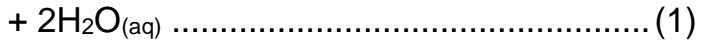

$\mathrm{ZnS}_{(\mathrm{s})}+\mathrm{H}_{2} \mathrm{SiF}_{6(\mathrm{aq})}+\mathrm{H}_{2} \mathrm{O}_{2(\mathrm{aq})} \rightarrow \mathrm{ZnSiF}_{6(\mathrm{aq})}+$ $\mathrm{SO}^{\mathrm{O}}+2 \mathrm{H}_{2} \mathrm{O}_{(\mathrm{aq})}$.

$\mathrm{FeS}_{2(\mathrm{~s})}+\mathrm{H}_{2} \mathrm{SiF}_{6(\mathrm{aq})} \rightarrow \mathrm{FeSiF}_{6(\mathrm{aq})}+2 \mathrm{~S}^{\mathrm{O}}+$ $2 \mathrm{H}_{2} \mathrm{O}_{(\mathrm{aq})}$

The chemical stability of hydrogen peroxide is very sensitive to temperature (Pecina et al., 2008) therefore the oxidant should be poured into the reactor in a short time interval. According to Pecina et al. (2008), the leaching of sulfide minerals in an acidic atmosphere follows the shrinking core model (SCM) which assume the particle size does not change and the particles are spherical.

Mathematical models for each type of reaction rate controller that follows the SCM are formulated as follows (Levenspiel, 1999). 
1. Diffusion through a fluid film on a mineral surface

$\frac{\mathrm{t}}{\mathrm{T}}=1-\left(1-\mathrm{X}_{\mathrm{T}}\right)=\mathrm{X}_{\mathrm{T}}$

$\mathrm{T}=\frac{\rho_{\mathrm{T}} \mathrm{R}}{3 \mathrm{b \textrm {k } _ { \mathrm { l } } \mathrm { C }}}$

2. Diffusion through layer of the porous solid product (ash)

$\frac{\mathrm{t}}{\mathrm{T}}=1-3\left(1-\mathrm{X}_{\mathrm{T}}\right)^{\frac{2}{3}}+2\left(1-\mathrm{X}_{\mathrm{T}}\right)$

$T=\frac{\rho_{\mathrm{T}} \mathrm{R}^{2}}{6 \mathrm{bD} \mathrm{D}_{\mathrm{e}} \mathrm{C}_{\mathrm{H}_{2} \mathrm{SiF}_{6}}}$

3. Interface reaction

$$
\begin{aligned}
& \frac{\mathrm{t}}{\mathrm{T}}=1-\left(1-\mathrm{X}_{\mathrm{T}}\right)^{\frac{1}{3}} \\
& \mathrm{~T}=\frac{\rho_{\mathrm{T}} \mathrm{R}}{\mathrm{bk} \mathrm{C}} \ldots \ldots \ldots \ldots \ldots \ldots \ldots \ldots
\end{aligned}
$$

Meanwhile the mathematical models of the controller following the SPM are formulated as follows (Levenspiel, 1999).

1. Diffusion through a fluid film on a mineral surface

$$
\begin{aligned}
& \frac{\mathrm{t}}{\mathrm{T}}=1-\left(1-\mathrm{X}_{\mathrm{T}}\right)^{\frac{2}{3}} \\
& \mathrm{~T}=\frac{\rho_{\mathrm{T}} \mathrm{R}^{2}}{2 \mathrm{bDC}} \ldots \ldots \ldots \ldots \ldots \ldots \ldots \ldots \ldots
\end{aligned}
$$

2. Interface reaction

$$
\frac{\mathrm{t}}{\mathrm{T}}=1-\left(1-\mathrm{X}_{\mathrm{T}}\right)^{\frac{1}{3}}
$$

$$
\mathrm{T}=\frac{\rho_{\mathrm{T}} \mathrm{R}}{\mathrm{bk} \mathrm{C}}
$$

where $t$ is the leaching time, $\mathrm{T}$ is the residence time of leaching until the metal sulfides in the galena concentrate has totally dissolved and $\mathrm{X}_{\mathrm{T}}$ is the total sulfides fraction that dissolves at the time $t$. For leaching of galena concentrate, it is assumed that the core is shrinking due to the dissolution of $\mathrm{PbS}, \mathrm{ZnS}$ and $\mathrm{FeS}_{2}$ and leaving sulfur behind so that $\mathrm{X}_{\mathrm{T}}$ is calculated from the total of the moles metallic sulfides dissolved and then it is divided by the moles of the metallic sulfides in the feed (galena concentrate), where $\mathrm{R}$ is the average of particles radius, $\rho$ T are the specific molar of the ore, $b$ is the ratio of the stoichiometric coefficient to the acid. $\mathrm{C}_{\mathrm{H}_{2} \mathrm{SiF}_{6}}$ is a concentration of the fluorosilicic acid reagent, $k_{l}$ is the diffusion coefficient in the diffusion film, De is the coefficient in the porous solid (ash) layer and $\mathrm{k}^{\mathrm{N}}$ is the reaction rate constant.

The experiments were performed for 150 minutes with a feed weight of $10.66 \mathrm{~g}$, stirrer speed of $300 \mathrm{rpm}, \mathrm{H}_{2} \mathrm{SiF}_{6}$ volume of 295.38 $\mathrm{ml}$ and $\mathrm{H}_{2} \mathrm{O}_{2}$ volume of $103.88 \mathrm{ml}$.

The procedure for conducting a kinetics study of leaching galena concentrate can be seen in the following flow chart (Figure 1).

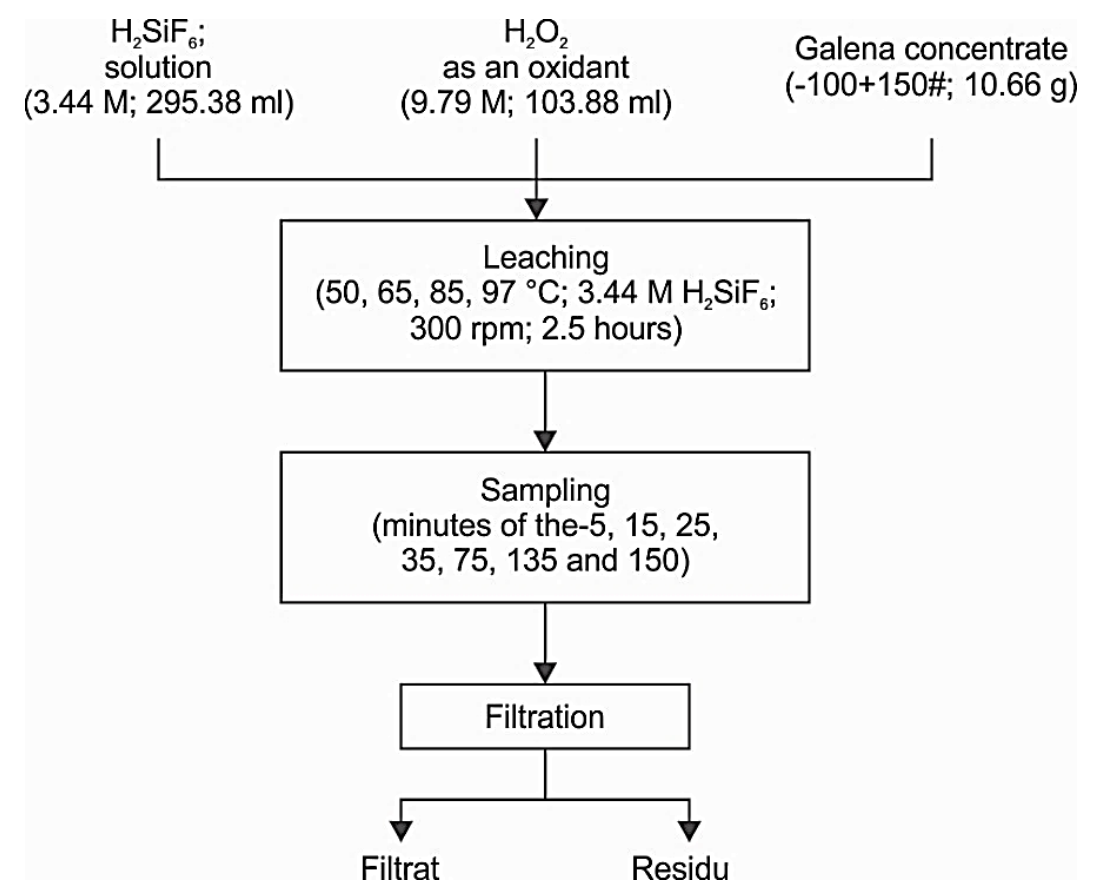

Figure 1. Experimental procedure of kinetics study of leaching galena concentrate 


\section{RESULTS AND DISCUSSIONS}

According to the previous research, Anugrah, Mubarok and Amalia (2018) has determined the chemical composition of the galena concentrate as the Table 1 shows.

Table 1. Chemical composition of the galena concentrate sample (as-received sample) (Anugrah, Amalia and Mubarok, 2018)

\begin{tabular}{cc}
\hline Element & Content (\%) \\
\hline $\mathrm{Pb}$ & 66.6 \\
$\mathrm{Zn}$ & 7.38 \\
$\mathrm{Cu}$ & 0.84 \\
$\mathrm{Fe}$ & 2.79 \\
$\mathrm{~S}$ Total & 17.62 \\
$\mathrm{Sb}$ & $<0.001$ \\
$\mathrm{Mo}$ & 0.12 \\
$\mathrm{Co}$ & $<0.001$ \\
\hline
\end{tabular}

It is assumed that the dissolved metallic sulfide minerals are $\mathrm{PbS}$ (galena), ZnS (sphalerite) and pyrite $\left(\mathrm{FeS}_{2}\right)$. By inputting the data of the $\mathrm{Pb}, \mathrm{Zn}$ and $\mathrm{Fe}$ metals dissolved in fluorosilicic acid and those of the Table 1, then the mole of the metallic sufides dissolved and $\mathrm{X}_{\mathrm{T}}$ can be calculated as shown by Table 2 .

According to Astuti et al. (2016), the kinetics of the leaching reaction were examined over a specific temperature range. Leaching kinetics analysis was carried out from leaching experiment data at 50,65, 85 and $97^{\circ} \mathrm{C}$. Profiles of the fraction of the total mole of the converted sulfide $\left(\mathrm{X}_{\mathrm{T}}\right)$ against time $(\mathrm{t})$ for each leaching temperature are presented in Figures 1 to 4.

Table 2. Calculation of $\mathrm{Pb}, \mathrm{Zn}$ and Fe sulfides dissolved mole and the fraction of the total dissolved sulfides $\left(\mathrm{X}_{\mathrm{T}}\right)$

\begin{tabular}{|c|c|c|c|c|c|c|c|c|c|c|c|c|c|}
\hline \multirow{2}{*}{$\begin{array}{c}\text { Temp. } \\
\left({ }^{\circ} \mathrm{C}\right)\end{array}$} & \multirow[t]{2}{*}{ Minutes } & \multirow[t]{2}{*}{ Hours } & \multicolumn{3}{|c|}{$\begin{array}{l}\text { Metals dissolved } \\
(\mathrm{g} / \mathrm{L})\end{array}$} & \multicolumn{3}{|c|}{$\begin{array}{l}\text { Mole of the dissolved } \\
\text { metals }\end{array}$} & \multicolumn{4}{|c|}{$\begin{array}{c}\text { Mole of the metallic sulfides } \\
\text { dissolved }\end{array}$} & \multirow[t]{2}{*}{$X_{T}$} \\
\hline & & & $\mathrm{Pb}$ & $\mathrm{Zn}$ & $\mathrm{Fe}$ & $\mathrm{Pb}$ & $\mathrm{Zn}$ & $\mathrm{Fe}$ & $\mathrm{PbS}$ & $\mathrm{ZnS}$ & $\mathrm{FeS}_{2}$ & Total & \\
\hline \multirow{8}{*}{50} & 0 & 0.00 & 0.00 & 0.00 & 0.00 & 0.0000 & 0.0000 & 0.0000 & 0.0000 & 0.0000 & 0.0000 & 0.0000 & 0.0000 \\
\hline & 5 & 0.08 & 1.87 & 0.05 & 0.06 & 0.0036 & 0.0003 & 0.0004 & 0.0036 & 0.0003 & 0.0004 & 0.0043 & 0.0841 \\
\hline & 15 & 0.25 & 2.89 & 0.13 & 0.11 & 0.0056 & 0.0008 & 0.0008 & 0.0056 & 0.0008 & 0.0008 & 0.0071 & 0.1385 \\
\hline & 25 & 0.42 & 3.79 & 0.30 & 0.15 & 0.0073 & 0.0018 & 0.0011 & 0.0073 & 0.0018 & 0.0011 & 0.0102 & 0.1978 \\
\hline & 35 & 0.58 & 4.71 & 0.33 & 0.18 & 0.0091 & 0.0020 & 0.0013 & 0.0091 & 0.0020 & 0.0013 & 0.0124 & 0.2399 \\
\hline & 75 & 1.25 & 7.33 & 0.58 & 0.26 & 0.0141 & 0.0035 & 0.0019 & 0.0141 & 0.0035 & 0.0019 & 0.0195 & 0.3784 \\
\hline & 135 & 2.25 & 7.58 & 0.70 & 0.30 & 0.0146 & 0.0043 & 0.0021 & 0.0146 & 0.0043 & 0.0021 & 0.0210 & 0.4075 \\
\hline & 150 & 2.50 & 7.94 & 0.72 & 0.30 & 0.0153 & 0.0044 & 0.0021 & 0.0153 & 0.0044 & 0.0021 & 0.0218 & 0.4233 \\
\hline \multirow{8}{*}{65} & 0 & 0.00 & 0.00 & 0.00 & 0.00 & 0.0000 & 0.0000 & 0.0000 & 0.0000 & 0.0000 & 0.0000 & 0.0000 & 0.0000 \\
\hline & 5 & 0.08 & 7.26 & 0.63 & 0.20 & 0.0140 & 0.0038 & 0.0014 & 0.0140 & 0.0038 & 0.0014 & 0.0193 & 0.3734 \\
\hline & 15 & 0.25 & 7.83 & 0.64 & 0.20 & 0.0151 & 0.0039 & 0.0014 & 0.0151 & 0.0039 & 0.0014 & 0.0204 & 0.3958 \\
\hline & 25 & 0.42 & 10.15 & 0.64 & 0.23 & 0.0196 & 0.0039 & 0.0016 & 0.0196 & 0.0039 & 0.0016 & 0.0251 & 0.4866 \\
\hline & 35 & 0.58 & 10.54 & 0.67 & 0.26 & 0.0203 & 0.0041 & 0.0019 & 0.0203 & 0.0041 & 0.0019 & 0.0263 & 0.5089 \\
\hline & 75 & 1.25 & 11.19 & 0.75 & 0.26 & 0.0216 & 0.0046 & 0.0019 & 0.0216 & 0.0046 & 0.0019 & 0.0280 & 0.5426 \\
\hline & 135 & 2.25 & 11.38 & 0.85 & 0.28 & 0.0219 & 0.0052 & 0.0020 & 0.0219 & 0.0052 & 0.0020 & 0.0291 & 0.5643 \\
\hline & 150 & 2.50 & 11.35 & 0.88 & 0.29 & 0.0219 & 0.0054 & 0.0021 & 0.0219 & 0.0054 & 0.0021 & 0.0293 & 0.5682 \\
\hline \multirow{8}{*}{85} & 0 & 0.00 & 0.00 & 0.00 & 0.00 & 0.0000 & 0.0000 & 0.0000 & 0.0000 & 0.0000 & 0.0000 & 0.0000 & 0.0000 \\
\hline & 5 & 0.08 & 12.40 & 0.50 & 0.18 & 0.0239 & 0.0031 & 0.0013 & 0.0239 & 0.0031 & 0.0013 & 0.0282 & 0.5472 \\
\hline & 15 & 0.25 & 10.40 & 0.74 & 0.23 & 0.0200 & 0.0045 & 0.0016 & 0.0200 & 0.0045 & 0.0016 & 0.0262 & 0.5078 \\
\hline & 25 & 0.42 & 15.37 & 0.79 & 0.24 & 0.0296 & 0.0048 & 0.0017 & 0.0296 & 0.0048 & 0.0017 & 0.0362 & 0.7007 \\
\hline & 35 & 0.58 & 14.75 & 0.84 & 0.25 & 0.0284 & 0.0051 & 0.0018 & 0.0284 & 0.0051 & 0.0018 & 0.0353 & 0.6848 \\
\hline & 75 & 1.25 & 14.35 & 1.02 & 0.28 & 0.0277 & 0.0062 & 0.0020 & 0.0277 & 0.0062 & 0.0020 & 0.0359 & 0.6954 \\
\hline & 135 & 2.25 & 13.04 & 1.52 & 0.59 & 0.0251 & 0.0093 & 0.0042 & 0.0251 & 0.0093 & 0.0042 & 0.0386 & 0.7486 \\
\hline & 150 & 2.50 & 14.96 & 1.77 & 0.72 & 0.0288 & 0.0108 & 0.0051 & 0.0288 & 0.0108 & 0.0051 & 0.0448 & 0.8678 \\
\hline \multirow{8}{*}{97} & 0 & 0.00 & 0.00 & 0.00 & 0.00 & 0.0000 & 0.0000 & 0.0000 & 0.0000 & 0.0000 & 0.0000 & 0.0000 & 0.0000 \\
\hline & 5 & 0.08 & 11.54 & 1.18 & 0.22 & 0.0222 & 0.0072 & 0.0016 & 0.0222 & 0.0072 & 0.0016 & 0.0310 & 0.6010 \\
\hline & 15 & 0.25 & 12.56 & 1.22 & 0.29 & 0.0242 & 0.0074 & 0.0021 & 0.0242 & 0.0074 & 0.0021 & 0.0337 & 0.6536 \\
\hline & 25 & 0.42 & 13.53 & 1.08 & 0.22 & 0.0261 & 0.0066 & 0.0016 & 0.0261 & 0.0066 & 0.0016 & 0.0342 & 0.6635 \\
\hline & 35 & 0.58 & 15.62 & 0.96 & 0.18 & 0.0301 & 0.0059 & 0.0013 & 0.0301 & 0.0059 & 0.0013 & 0.0372 & 0.7218 \\
\hline & 75 & 1.25 & 16.41 & 0.93 & 0.21 & 0.0316 & 0.0057 & 0.0015 & 0.0316 & 0.0057 & 0.0015 & 0.0388 & 0.7519 \\
\hline & 135 & 2.25 & 16.20 & 1.50 & 0.16 & 0.0312 & 0.0092 & 0.0011 & 0.0312 & 0.0092 & 0.0011 & 0.0415 & 0.8046 \\
\hline & 150 & 2.50 & 17.08 & 2.67 & 0.16 & 0.0329 & 0.0163 & 0.0011 & 0.0329 & 0.0163 & 0.0011 & 0.0504 & 0.9759 \\
\hline
\end{tabular}




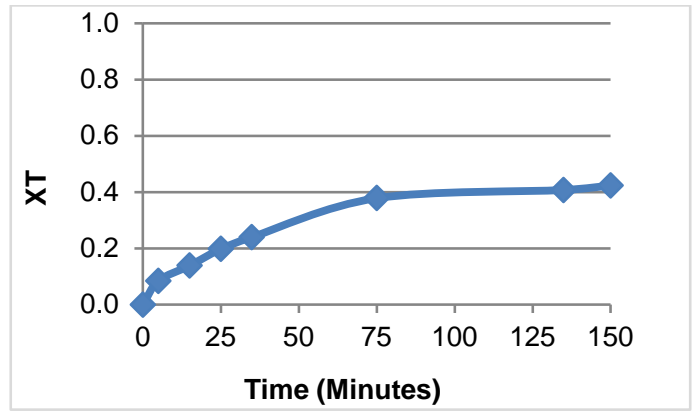

Figure 1. $\mathrm{X}_{\mathrm{T}}$ profile against $\mathrm{t}$ from $50^{\circ} \mathrm{C}$ experiment

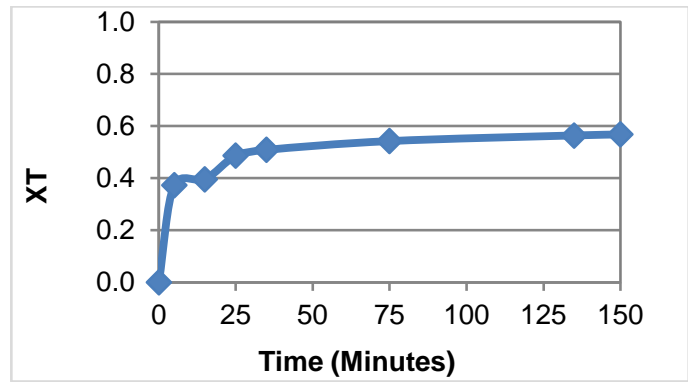

Figure 2. $\mathrm{XT}_{\mathrm{T}}$ profile against $\mathrm{t}$ from $65^{\circ} \mathrm{C}$ experiment

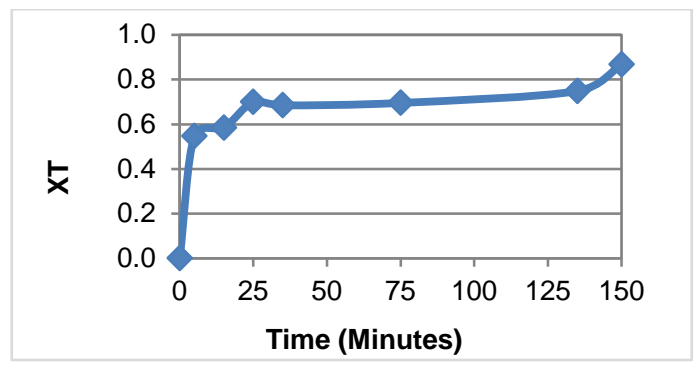

Figure $3 . \mathrm{X}_{\mathrm{T}}$ profile against $\mathrm{t}$ from $85^{\circ} \mathrm{C}$ experiment

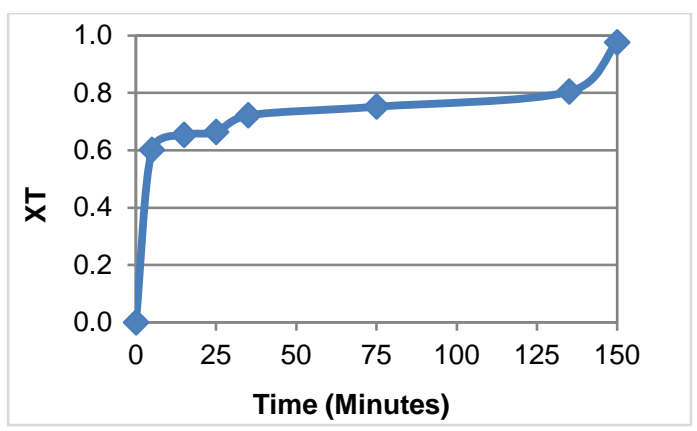

Figure 4. $\mathrm{X}_{\mathrm{T}}$ profile against $\mathrm{t}$ from $97^{\circ} \mathrm{C}$ experiment
Figure 1 shows the total mole of the converted sulfide increased as the leaching times increased. Figure 2 to 4 show the similar tendency compared to Figure 1 but after 15 minutes of leaching, the $\mathrm{X}_{T}$ slightly declined then rose following the increase in temperature. The $X_{T}$ declined at minutes of 15 because there was a probably porous solid product formation which will be examined in the next stage.

Based on the SCM, the reaction kinetics will be controlled by (Şahin and Erdem, 2015):

1. Diffusion through fluid film if the plot of $X_{T}$ and $t$ was linear

2. Diffusion through the porous solid product (ash) layer if plot of $1-3\left(1-X_{T}\right)^{2 / 3}+2\left(1-X_{T}\right)$ and $t$ was linear

3. Interface reaction if the plot of $1-\left(1-\mathrm{X}_{\mathrm{T}}\right)^{1 / 3}$ and $t$ was linear.

Meanwhile, based on the SPM, the reaction kinetics will be controlled by:

1. Diffusion through fluid film if the plot of 1$\left(1-X_{T}\right)^{2 / 3}$ and $t$ was linear

2. Chemical reaction on the interface if the plot of $1-\left(1-X_{T}\right)^{1 / 3}$ and $t$ was linear.

All of those plots, both SCM and SPM are presented at these following Figures 5 to 9:

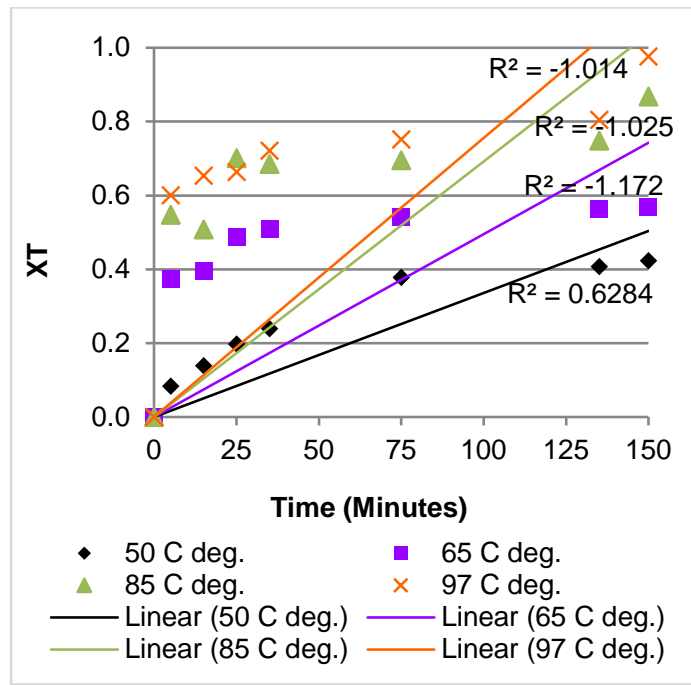

Figure 5. Plot and linear regression of $\mathrm{X}_{\mathrm{T}}$ to $\mathrm{t}$ (times) for SCM 


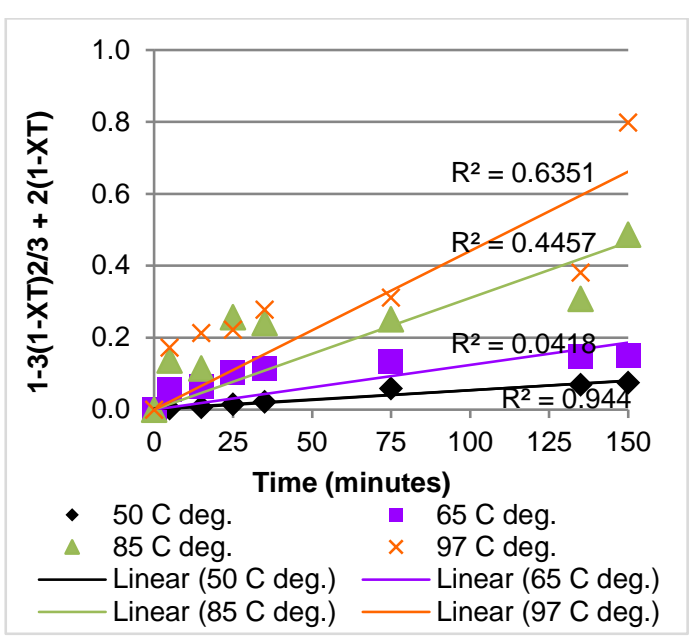

Figure 6. Plot and linear regression of $1-3\left(1-\mathrm{X}_{\mathrm{T}}\right)^{2 / 3}$ $+2\left(1-X_{T}\right)$ to $t$ (times) for SCM

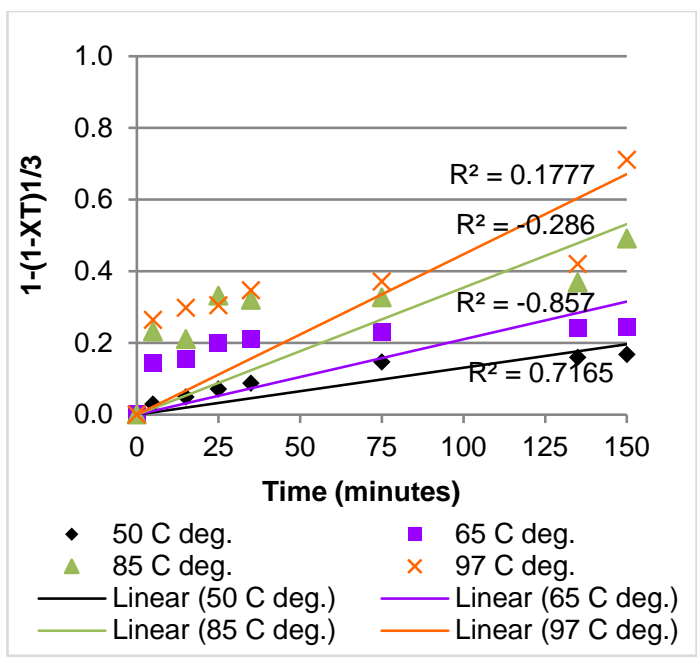

Figure 7. Plot and linear regression of $1-\left(1-\mathrm{X}_{\mathrm{T}}\right)^{1 / 3}$ to $t$ (times) for SCM

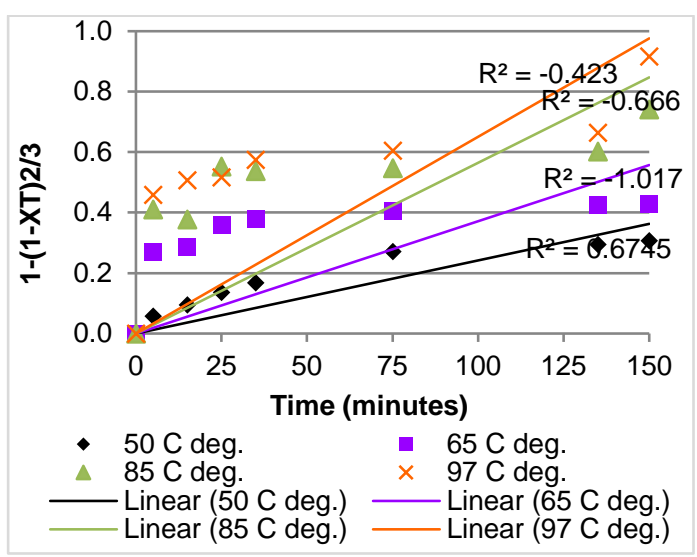

Figure 8. Plot and linear regression of 1-(1- $\left.\mathrm{X}_{\mathrm{T}}\right)^{2 / 3}$ to $t$ (times) for SPM

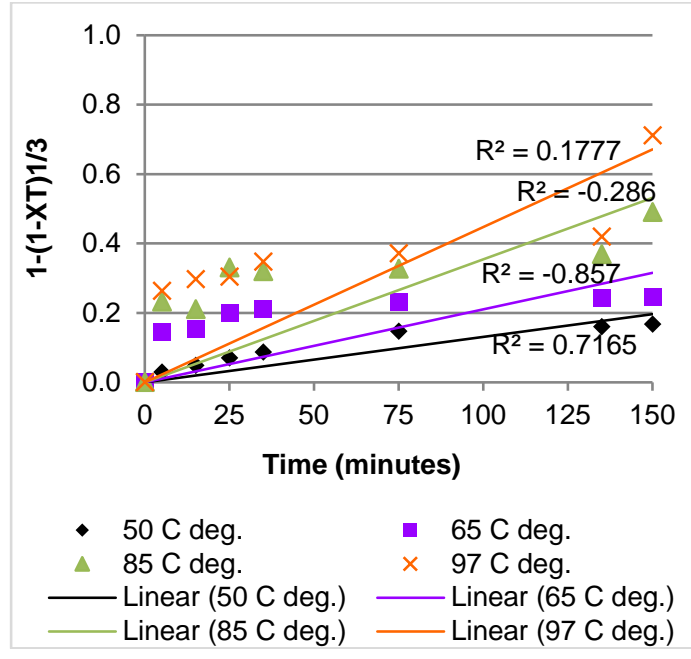

Figure 9. Plot and linear regression of $1-\left(1-\mathrm{X}_{\mathrm{T}}\right)^{1 / 3}$ to $t$ (times) for SPM

A summary of $R^{2}$ values which was obtained from the linear regression equations of experimental data with all the kinetic models was used for each leach temperature and presented in Table 3.

Based on Table 3, the value of $\mathrm{R}^{2}$ which close to 1 was obtained from the experimental data of the linear regression of SCM for porous solild layer diffusion. It concludes that the most suitable model for analyzing the leaching kinetics of galena concentrate in fluorosilicic acid solution was a SCM model with diffusion of porous solid product layer as chemical reaction controller.

The selection of reaction rate controller was also done by a method which is fitting the curve from the dummy model to the experimental data. For this purpose, the value of $\tau$ (time needed for all minerals to react completely when $X_{T}=1$ ) needs to be calculated first. The value of $\tau$ was determined from the slopes of all linear equations following the SCM for porous solid layer diffusion as reaction controller since its $\mathrm{R}^{2}$ was closer to 1 than other types have. $\tau=$ 1/slope was determined from linear regression of $1-3\left(1-\mathrm{X}_{\mathrm{T}}\right) 2 / 3+2\left(1-\mathrm{X}_{\mathrm{T}}\right)$ to $\mathrm{t}$. Table 4 presents the values of $\tau$ from leaching at $50,65,85$ and $97^{\circ} \mathrm{C}$.

From the values of $\tau$, dummy curve was constructed that was fitting to the experimental data by plotting the values of $\mathrm{X}_{T}$ orderly from 0 to 1 and determined the time that was suitable for the simulated $X_{T}$. This 
procedure was conducted for all the leaching temperatures. The result for fitting the dummy curve to the experimental data is presented at Figures 10 to 13.

Table 3. Summary of $R^{2}$ values which is obtained from the linear regression equations of experimental data with all the kinetic models used for each leach temperature

\begin{tabular}{cccccc}
\hline \multirow{2}{*}{$\begin{array}{c}\text { Temperature } \\
\left({ }^{\circ} \mathrm{C}\right)\end{array}$} & \multicolumn{3}{c}{$\mathrm{R}^{2}$ for each kinetics models of reaction rate controller } \\
\cline { 2 - 5 } & $\begin{array}{c}\text { Fluid film } \\
\text { diffusion }\end{array}$ & $\begin{array}{c}\text { Porous layer } \\
\text { diffusion }\end{array}$ & $\begin{array}{c}\text { Interface } \\
\text { reaction }\end{array}$ & $\begin{array}{c}\text { Fluid film } \\
\text { diffusion }\end{array}$ & $\begin{array}{c}\text { Interface } \\
\text { reaction }\end{array}$ \\
\hline 50 & 0.628 & 0.944 & 0.716 & 0.674 & 0.716 \\
65 & -1.88 & 0.041 & -1.67 & -1.78 & -1.67 \\
85 & -1.02 & 0.445 & -0.28 & -0.66 & -0.28 \\
97 & -1.01 & 0.635 & 0.177 & -0.42 & 0.177 \\
\hline
\end{tabular}

Table 4. The determination of $\tau$ from the line equations of the diffusion through porous solid layer

\begin{tabular}{ccccc}
\hline Temperature $\left({ }^{\circ} \mathrm{C}\right)$ & Equation & Slope & $\tau$ (minutes) & $\tau$ (hours) \\
\hline 50 & $\mathrm{y}=0.0005 \mathrm{x}$ & 0.0005 & 2000.00 & 33.33 \\
65 & $\mathrm{y}=0.001 \mathrm{x}$ & 0.001 & 1000.00 & 16.67 \\
85 & $\mathrm{y}=0.003 \mathrm{x}$ & 0.003 & 333.33 & 5.56 \\
97 & $\mathrm{y}=0.004 \mathrm{x}$ & 0.004 & 250.00 & 4.17 \\
\hline
\end{tabular}

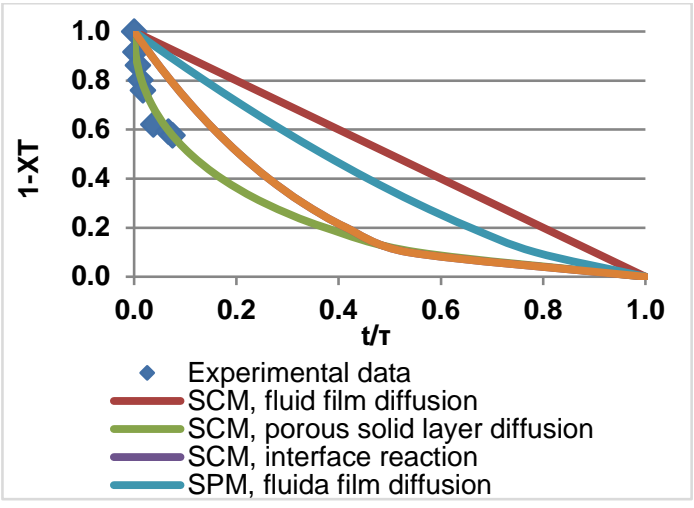

Figure 10. Fitting dummy curve model to experimental data at $50^{\circ} \mathrm{C}$ leaching temperature

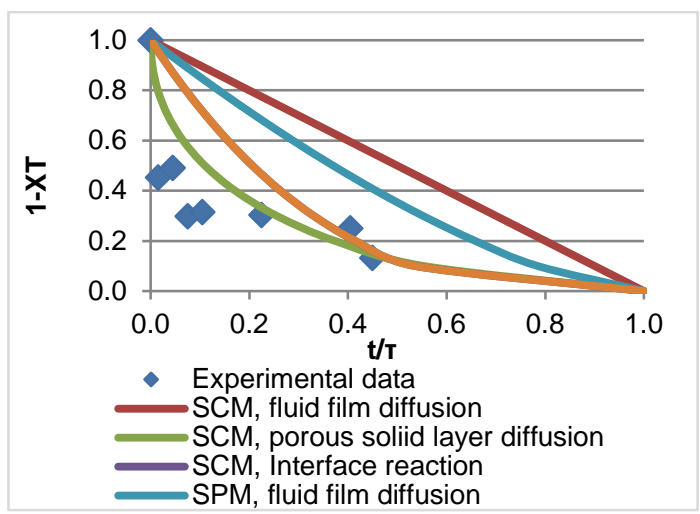

Figure 11. Fitting dummy curve model to experimental data at $65^{\circ} \mathrm{C}$ leaching temperature

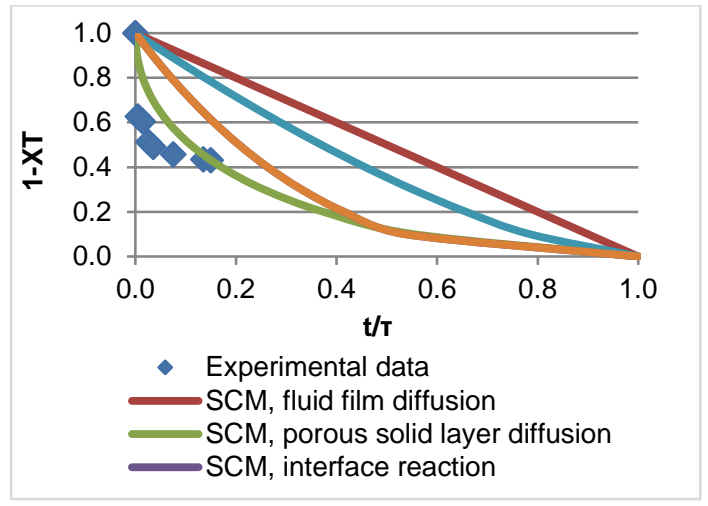

Figure 12. Fitting dummy curve model to experimental data at $85^{\circ} \mathrm{C}$ leaching temperature

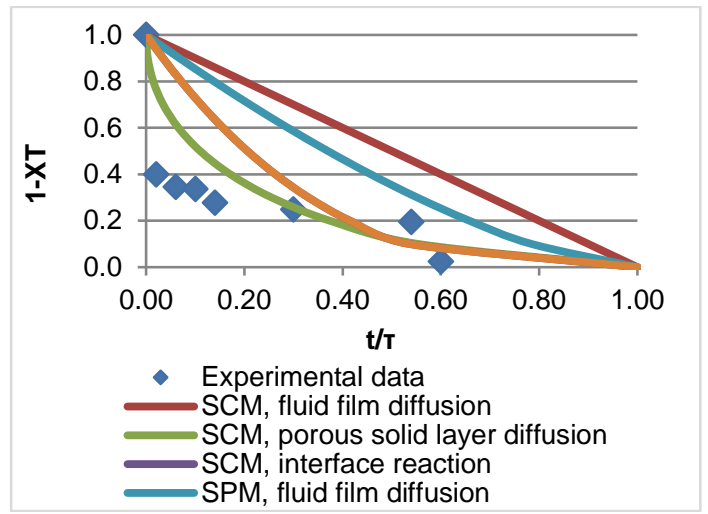

Figure 13. Fitting dummy curve model to experimental data at $97^{\circ} \mathrm{C}$ leaching temperature 
From all the graphs in the dummy models to the experimental data fitting curves, it shows that the dummy curve of the SCM kinetics model was controlled by diffusion through a porous solid layer which was the closest to the experimental data.This curve fitting result convinces the previous conclusion which used kinetics analysis with linear regression. Again, the reaction rate of the galena concentrate leaching in fluorosilicic acid was controlled by the diffusion through the porous solid products (ash) layer.

Activation energy $\left(E_{a}\right)$ is determined from the Arrhenius equation for diffusion controller through the porous solid products (ash) layer (Levenspiel, 1999):

$D_{e}=D_{0} \exp \left(\frac{-E_{a}}{R T}\right)$

or

$\ln D_{e}=-\frac{E_{a}}{R T}+\ln D_{0}$

By plotting 1-3(1- $\left.\mathrm{X}_{\mathrm{T}}\right)^{2 / 3}+2\left(1-\mathrm{X}_{\mathrm{T}}\right)$ to $\mathrm{t}$ (time), the gradient or slope $(\mathrm{m})$ was determined and thus $D_{e}$ was also calculated by using the following formula.

$D_{e}=m \frac{\rho_{T} R^{2}}{6 b C_{\mathrm{H}_{2} \mathrm{SiF}_{6}}}$

Where $\rho_{T}$ is total sulfide molar density, $R$ is particle radius, $\mathrm{C}_{\mathrm{H}_{2} \mathrm{SiF}_{6}}$ is fluorosilicic acid concentration and $b$ is stoichiometric ratio of feed to fluorosilicic acid. The concentration of the fluorosilicic acid was $3.44 \mathrm{M}$ or $\mathrm{C}_{\mathrm{H}_{2} \mathrm{SiF}_{6}}$ $=3.44 \mathrm{~mol} / \mathrm{litre}=3,440 \mathrm{~mol} / \mathrm{m}^{3}$. Total sulfide molar density was calculated by the following formula:

$\rho_{\mathrm{T}}=\frac{\text { total sulfide mol }}{\text { total volume }}$
The galena spesific density was $6.04 \mathrm{~g} / \mathrm{cm}^{3}$ $\left(6,040 \mathrm{~kg} / \mathrm{m}^{3}\right)$. The kinetics experiment was performed by using $10.66 \mathrm{~g}$ feed so that the total sulfide mol of $\mathrm{PbS}, \mathrm{ZnS}$ and $\mathrm{FeS}_{2}$ dissolved was $0.0516 \mathrm{~mol}$. These data was put into equation (17)

$\rho_{\mathrm{T}}=\frac{0.0516 \mathrm{~mol} \times 6,040 \mathrm{~kg} / \mathrm{m}^{3}}{10,66 \mathrm{gram}}$

$\rho_{\mathrm{T}}=29,236.77 \mathrm{~mol} / \mathrm{m}^{3}$

The feed particle size $\left(\mathrm{P}_{80}\right)$ was $-100+150$ mesh, therefore the average diameter of the particles was

$$
\begin{aligned}
& D=\frac{(100+150) \text { mesh }}{2} \\
& D=\frac{(0.149+0.100) \mathrm{mm}}{2}=0.1245 \mathrm{~mm}
\end{aligned}
$$

or the particles radius $(R)$ was

$$
\begin{aligned}
R & =\frac{D}{2}=\frac{0.1245 \mathrm{~mm}}{2} \\
& =0.0622 \mathrm{~mm}
\end{aligned}
$$

$R=0.0622 \times 10^{-3} \mathrm{~m}$

Based on the previous experiment (Anugrah, Mubarok and Amalia, 2018), the values and the $b$ of the converted mole fractions from the dissolution of galena concentrate's mineral sulfides, are presented in Table 5.

The next step was calculating $D_{e}$ based on equation (16) from the gradient of the line equation for porous solid layer diffusion at different leaching temperatures. Then $1 / T$

\begin{tabular}{|c|c|c|c|c|c|c|c|c|c|c|}
\hline Sulfides & \multicolumn{2}{|c|}{ Content } & Feed weight $(\mathrm{g})$ & \multicolumn{2}{|c|}{ Weight (g) } & \multicolumn{2}{|c|}{ Mole } & Mole fraction (X) & b & bX \\
\hline $\mathrm{PbS}$ & $\mathrm{Pb}$ & $66.60 \%$ & & $\mathrm{~Pb}$ & 7.0996 & $\mathrm{PbS}$ & 0.0343 & 0.6638 & 1 & 0.6638 \\
\hline ZnS & $\mathrm{Zn}$ & $7.38 \%$ & 10.66 & $\mathrm{Zn}$ & 0.7867 & ZnS & 0.0120 & 0.2331 & 1 & 0.2331 \\
\hline $\mathrm{FeS}_{2}$ & $\mathrm{Fe}$ & $2.79 \%$ & & $\mathrm{Fe}$ & 0.2974 & $\mathrm{FeS}_{2}$ & 0.0053 & 0.1032 & 1 & 0.1032 \\
\hline Total & & & & & & & 0.0516 & 1.0000 & & 1.0000 \\
\hline
\end{tabular}
and $\ln D_{e}$ were also calculated according to Table 6.

Table 5. The calculation of the sulfide minerals converted fraction and the value of $b$ 
Table 6. In $D_{e}$ and 1/T calculation

\begin{tabular}{|c|c|c|c|c|c|}
\hline \multicolumn{2}{|c|}{ Temperature } & \multirow{2}{*}{ Slope (m) } & \multirow{2}{*}{$\mathrm{De}_{\mathrm{e}}(\mathrm{m} / \mathrm{s})$} & \multirow{2}{*}{$1 / T$} & \multirow{2}{*}{ In $D_{e}$} \\
\hline${ }^{\circ} \mathrm{C}$ & $\mathrm{K}$ & & & & \\
\hline 50 & 323 & 0.0005 & $2.74013 \mathrm{E}-12$ & 0.003096 & -26.6230 \\
\hline 65 & 338 & 0.0010 & $5.48025 \mathrm{E}-12$ & 0.002959 & -25.9299 \\
\hline 85 & 358 & 0.0030 & 1.64408E-11 & 0.002793 & -24.8313 \\
\hline 97 & 370 & 0.0040 & 2.1921E-11 & 0.002703 & -24.5436 \\
\hline
\end{tabular}

Plotting In De to $1 / T$ results in a graph at Figure 14.

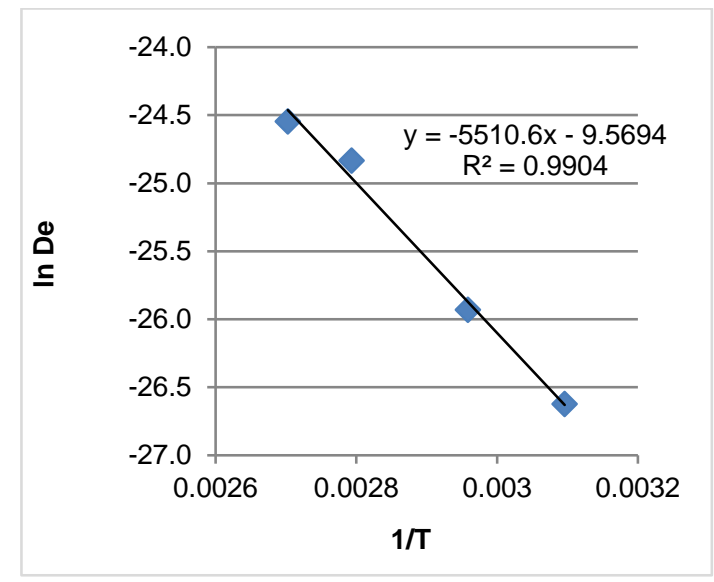

Fifure 14. Plot of In De to $1 / T$

According to Figure 14, plotting In De to $1 / T$ resulted in a linear line equation $\left(R^{2}=0.99\right)$ with a gradient of $-5,510$. The activation energy was then calculated by this following calculation.

$$
\text { Activation energy } \begin{aligned}
\left(\mathrm{E}_{\mathrm{a}}\right)= & \text { gradient } \times \mathrm{R} \\
= & 5,510 \mathrm{~K} \times 8.3143 \\
& \mathrm{~J} / \mathrm{K} / \mathrm{mol} \\
= & 45,811.79 \mathrm{~J} / \mathrm{mol} \\
= & 45.81 \mathrm{~kJ} / \mathrm{mol} \\
= & 10.91 \mathrm{kcal} / \mathrm{mol}
\end{aligned}
$$

Activation energy of $45.81 \mathrm{~kJ} / \mathrm{mol}$ for diffusion-controlled reactions through porous solid layer can be catagorized as high. According to Randhawa, Gharami and Kumar (2016), for the reaction that was controlled by diffusion mechanism, $E_{a}$ ranged between 1 to $3 \mathrm{kcal} / \mathrm{mol}$ and higher if it was controlled by chemical reaction. The high activation energy is was probably afffected by $\mathrm{Pb}$ existence which undissolved because it reacted with $\mathrm{SO}_{4}^{2-}$ ion forming $\mathrm{PbSO}_{4}$ precipitate (ZárateGutiérrez, Lapidus and Morales, 2012). It can also be affected by a mineral existence which has low solubility in fluorosilicic acid such as chalcopyrite ( $\left.\mathrm{CuFeS}_{2}\right)$ (Zárate-Gutiérrez, Lapidus and Morales, 2010).

\section{CONCLUSION}

Leaching Indonesian galena concentrate in flurosilicic acid and hydrogen peroxide as oxidants followed the shrinking core model with diffusion through porous solid product layer as the reaction controller with activation energy of $45.81 \mathrm{~kJ} / \mathrm{mol}$ or $10.91 \mathrm{kcal} / \mathrm{mol}$.

\section{ACKNOWLEDGEMENT}

The authors would like to express gratitude to the $R$ \& $D$ Center for Mineral and Coal Technology for funding this research. The authors would also acknowledge the role of Indonesian Mining Journal editors for their assistance and direction to improve the quality of this paper.

\section{REFERENCES}

Anugrah, R. I., Mubarok, M. Z. and Amalia, D. (2017) 'Study on the leaching behavior of galena concentrate in fluosilicic acid solution using hydrogen peroxide as oxidant', in Proceedings of the 1st International Process Metallurgy Conference (IPMC 2016). Bandung: American Institute of Physics, pp. 0300061-030006-7. doi: 10.1063/1.4974417.

Anugrah, R. I., Mubarok, M. Z. and Amalia, D. (2018) 'Parameters that affect the dissolution of Indonesian galena concentrate in fluorosilicic acid and hydrogen peroxide', Indonesian Mining Journal, 21(2), pp. 89-97. doi: 10.30556/imj.Vol21.No2.2018.677.

Astuti, W., Hirajima, T., Sasaki, K. and Okibe, N. (2016) 'Comparison of atmospheric citric acid leaching kinetics of nickel from different Indonesian saprolitic ores', Hydrometallurgy, 161, pp. 138-151. doi: 10.1016/j.hydromet.2015.12.015. 
Aydoğan, S., Erdemoğlu, M., Uçar, G. and Aras, A. (2007) 'Kinetics of galena dissolution in nitric acid solutions with hydrogen peroxide', Hydrometallurgy, 88(1-4), pp. 52-57.

doi: 10.1016/j.hydromet.2007.03.005.

Levenspiel, O. (1999) 'Chemical reaction engineering', Industrial \& Engineering Chemistry Research, 38(11), pp. 41404143. doi: 10.1021/ie990488g.

Pecina, T., Franco, T., Castillo, P. and Orrantia, E. (2008) 'Leaching of a zinc concentrate in $\mathrm{H} 2 \mathrm{SO} 4$ solutions containing $\mathrm{H} 2 \mathrm{O} 2$ and complexing agents', Minerals Engineering, 21(1), pp. 23-30. doi: 10.1016/j.mineng.2007.07.006.

Randhawa, N. S., Gharami, K. and Kumar, M. (2016) 'Leaching kinetics of spent nickelcadmium battery in sulphuric acid', Hydrometallurgy, 165, pp. 191-198. doi: 10.1016/j.hydromet.2015.09.011.
Şahin, M. and Erdem, M. (2015) 'Cleaning of high lead-bearing zinc leaching residue by recovery of lead with alkaline leaching', Hydrometallurgy, 153, pp. 170-178. doi: 10.1016/j.hydromet.2015.03.003.

Zárate-Gutiérrez, R., Lapidus, G. T. and Morales, R. D. (2010) 'Pressure leaching of a lead-zinc-silver concentrate with nitric acid at moderate temperatures between 130 and $170^{\circ} \mathrm{C}^{\prime}$, Hydrometallurgy, 104(1), pp. 8-13. doi: 10.1016/j.hydromet.2010.04.001

Zárate-Gutiérrez, R., Lapidus, G. T. and Morales, R. D. (2012) 'Aqueous oxidation of galena and pyrite with nitric acid at moderate temperatures', Hydrometallurgy, 115-116, pp. 57-63.

doi: 10.1016/j.hydromet.2011.12.010. 